\title{
EXCHANGE RATE SYSTEMS AND POLICIES IN ASIA
}


This page intentionally left blank 


\section{EXCHANGE RATE}

SYSTEMS AND

\section{POLICIES IN ASIA}

\section{Editor}

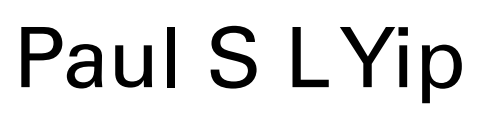

Nanyang Technological University, Singapore 


\section{Published by}

World Scientific Publishing Co. Pte. Ltd.

5 Toh Tuck Link, Singapore 596224

USA office: 27 Warren Street, Suite 401-402, Hackensack, NJ 07601

UK office: 57 Shelton Street, Covent Garden, London WC2H 9HE

\section{British Library Cataloguing-in-Publication Data}

A catalogue record for this book is available from the British Library.

\section{EXCHANGE RATE SYSTEMS AND POLICIES IN ASIA}

Copyright (@ 2008 by World Scientific Publishing Co. Pte. Ltd.

All rights reserved. This book, or parts thereof, may not be reproduced in any form or by any means, electronic or mechanical, including photocopying, recording or any information storage and retrieval system now known or to be invented, without written permission from the Publisher.

For photocopying of material in this volume, please pay a copying fee through the Copyright Clearance Center, Inc., 222 Rosewood Drive, Danvers, MA 01923, USA. In this case permission to photocopy is not required from the publisher.

ISBN-13 978-981-283-450-8

ISBN-10 981-283-450-8

Typeset by Stallion Press

Email: enquiries@stallionpress.com

Printed in Singapore. 


\section{CONTENTS}

Introduction: Important Lessons from Some Major Exchange Rate and Monetary Experiences in Asia

Paul S. L. Yip

The International Monetary Fund and Exchange Rate Crisis Management Chong-Yah Lim

The Case for an Intermediate Exchange Rate Regime

John Williamson

Japan's Deflationary Hangover: Wage Stagnation and the Syndrome of the Ever-Weaker Yen

Ronald McKinnon

Managing Flexibility: Japanese Exchange Rate Policy, 1971-2007

Shinji Takagi

China's Exchange Rate System Reform

Paul S. L. Yip

The Fog Encircling the Renminbi Debate

Yin-Wong Cheung, Menzie D. Chinn and Eiji Fujii

Insulation of India from the East Asian Crisis: An Analysis

Pami Dua and Arunima Sinha

Singapore's Exchange Rate Policy: Some Implementation Issues

Hwee-Kwan Chow 
This page intentionally left blank 


\title{
INTRODUCTION: IMPORTANT LESSONS FROM SOME MAJOR EXCHANGE RATE AND MONETARY EXPERIENCES IN ASIA
}

\author{
PAUL S. L. YIP \\ Division of Economics, School of Humanities and Social Sciences \\ Nanyang Technological University, Nanyang Avenue, Singapore 639798 \\ aslyip@ntu.edu.sg
}

\section{Introduction}

This book volume, reprinted from the Singapore Economic Review (Vol. 52, No. 3), consists of eight insightful policy papers on the exchange rate systems and policies in Asia. As this volume is targeted at policymakers as well as academia and professionals in economics and finance, this Introduction links and elaborates the most important discussions in these papers on an issue-by-issue basis. This non-traditional format will enable me to highlight the important lessons from some major exchange rate and monetary experiences in Asia in a consistent and organic way. In addition, the Introduction links and elaborates only those discussions that the editor strongly agrees with. Thus, policymakers can be confident with the conclusions, which include some relatively revolutionary hypotheses drawn from the discussions. It is hoped that this volume will serve as a very useful handbook that policymakers can easily refer to whenever they encounter the major economic issues discussed here. This is particularly the case for other developing economies who are adopting a fixed exchange rate system, making the choice between capital control and capital account liberalization, seeking ways to reduce huge non-performing bank loans, or at the early stage of a rampant asset inflation era.

Before elaborating on the major lessons, let us first have a very brief overview of the eight papers collected in this volume. The first paper is on the International Monetary Fund and exchange rate crisis management, by Chong-Yah Lim. After giving a brief discussion of the economic performance of the old ASEAN 6 (i.e., Brunei, Indonesia, Malaysia, Philippines, Singapore and Thailand), the new ASEAN 4 (i.e., Cambodia, Laos, Myanmar and Vietnam) and China during and after the Asian financial crisis in 1997, Lim challenges the "Washington Consensus" which includes no capital control under any circumstances. It also highlights the enormous risk of having capital account liberalization before domestic economic liberalization.

Next is John Williamson's paper on the choice of exchange rate systems. After a concise and pertinent review on the advantages and disadvantages of fixed, floating, adjustable and 
BBC (i.e., basket, band and crawl) regimes, Williamson challenges the Bipolarity Thesis (i.e., regimes other than firmly-fixed and freely-floating rates are infeasible) and highlights that an intermediate exchange rate regime such as a reference rate system could be a better choice.

The third and fourth papers are by Ronald McKinnon and Shinji Takagi, respectively, who have provided very detailed and insightful discussions on the exchange rate policies in Japan since the breakdown of the Bretton Woods System in 1971. In particular, McKinnon has made extremely insightful and interesting discussions on how: (i) the Japanese economy is currently caught by the perceived risk of yen appreciation; and (ii) the Bank of Japan is forced to stop the appreciation whenever there is a run for yen. As failure to contain future runs could imply disastrous global financial instability, I urge readers to have a very careful look at the paper with deep following-up thoughts on the consequences and solutions of the problem (see also the discussion in Section 4). Takagi's paper also suggests that: (i) Japan's exchange rate system is not as purely floating as many economists have been assuming; and (ii) Japan's experiences of using foreign exchange market intervention, change in capital control regulations, and other measures in influencing the exchange value of yen could be useful for other developing economies in the future.

The fifth paper, by Paul S. L. Yip, and the sixth paper, by Yin-Wong Cheung, Menzie D. Chinn and Eiji Fujii, are very up-to-date papers on China's exchange rate system, monetary policies and macroeconomic conditions. Yip notes that China's transitional exchange rate system reform in 2005 and banking reform in 2005-2006 were relatively successful, but the real risk of China and her reform are the stock market bubble, the rampant property inflation and rising CPI inflation since 2006-2007. If China fails to stop the asset bubble from expanding further, then a bursting of the bubble will be just a matter of time. In the worst scenario, this could result in political and social instability in China as well as serious economic disruptions or recessions in the regional, and perhaps the global, economies. In their policy paper in this volume and their econometric paper in the Journal of International Money and Finance, Cheung et al. highlight that empirical evidence for the US's claim of renminbi undervaluation is in fact very weak (i.e., statistically insignificant) with extremely imprecise estimates. Although this does not mean that there is no undervaluation, the paper emphasizes that renminbi appreciation in and of itself is unlikely to alter the basic problem of a massive US trade deficit. That problem is first and foremost a "made-in-America" issue, driven by collapsed household and public sector savings, and US's heavy dependence upon imported oil. It would also be an enormous mistake to think that a stronger renminbi is a panacea for what ails the US.

The seventh paper, by Pami Dua and Arunima Sinha, provides a detailed review of India's experience since her economic crisis in 1990-1991, the reforms made after the 1990-1991 crisis, and India's relative insulation from the Asian financial crisis in 1997-1998. Given the huge population and the rising importance of India, the paper also enables economists and policymakers in East Asia to have a relatively good understanding of an economy that could be extremely important to them in the future.

Finally, Hwee-Kwan Chow discusses some implementation issues on the exchange rate system and policies in Singapore. It should be noted that discussion on Singapore's exchange 
rate system is no less important than those of the three large Asian economies (i.e., Japan, China and India). The successful system in Singapore suggests that it could be a role model for other economies. In fact, as reported by Yip's paper in this volume, many of the useful settings and system designs were, and are going to be, adopted by China with appropriate modifications. If China is able to control her asset bubble and make no major mistake in her exchange rate system reform, there is a good chance that the useful settings and experience in Singapore will be adopted by many other developing economies (with appropriate modifications) in the future.

\section{Lessons on the Choice of Exchange Rate Systems}

Let us start with the lessons that can be drawn on the choice of exchange rate systems, which is in fact the first and most important international monetary decision of any economy. As we will see, the discussion is particularly important for those economies adopting a fixed exchange rate system, and those economies considering the costs and benefits of various exchange rate regimes.

\subsection{The risks and costs of a fixed exchange rate system}

In the second paper of this volume, Williamson provides a concise and updated review of the costs and benefits of a fixed exchange rate system. The paper first notes that the often-cited gain of lower transaction costs of a fixed exchange rate system may be true within a monetary area, but less true for a currency board and other fixed exchange rate system. Even for the former, the gain is likely to be rather small (i.e., it could not be a strong case for a fixed exchange rate system, especially if there are other major costs with a fixed exchange rate system). It also provides the following challenge on another often-cited argument for a fixed rate system: the provision of a nominal anchor of a fixed exchange rate involves an implicit and unrealistic assumption of zero-degree homogeneity among the economies in the fixed rate system. Williamson also highlights that there are many examples of countries that have disruptive adjustments of their real exchange rate in a manner contradictory to the nominal anchor argument: one might, for example, cite the East Asian countries in 1997 and India in 1991-1992 (see Dua and Sinha, the seventh paper of this volume).

On the other hand, the costs of a fixed exchange rate system are that it will deprive the economy of (i) a potent expenditure-switching instrument (i.e., using exchange rate changes to switch demand between domestic and foreign outputs); and (ii) an independent monetary policy (i.e., to finetune domestic aggregate demand) if there is free mobility of capital. Besides, under a fixed exchange rate system, the restoration of full employment output will rely on the adjustment of prices and wages. However, it is well-known that prices and wages are highly sluggish in the downward direction (see Yip and Wang, 2001, 2002 for the empirical evidence on Singapore and Hong Kong). As a result, any shock causing a reduction in internal or external demand, or an overvaluation of domestic currency could imply huge economic adjustment costs in terms of low output and high unemployment for a prolonged period. One very good example is detailed in Yip (2005a, 2002): after detailed 
theoretical and empirical discussions, the book and paper conclude that the fixed exchange rate in Hong Kong's currency board system and the greater flexibility of exchange rate in Singapore were the main reasons for a less severe recession in Singapore during the 1997 Asian crisis and post-crisis period, although Singapore's economic, financial and trading relationships with the crisis-hit economies were much greater than that of Hong Kong.

After highlighting the likelihood (and high cost) of an eventual abrupt adjustment in real exchange rate under a fixed rate system, Williamson lists a set of conditions for a policy of fixing exchange rate to make sense. From the list, one can easily recognize that many economies adopting a fixed exchange rate system do not satisfy these conditions. In particular, Williamson regards Hong Kong's peg with the US dollar as anomalous as her economic relationship with China and other East Asian economies are much greater than that with the US (i.e., violation of the zero-degree homogeneity assumption).

\subsection{Major misalignments could also happen in a floating regime}

Williamson notes that major exchange rate misalignments could also happen in a floating regime. The currently well-known undervaluation of the yen is one example (see the discussion in Section 4 and McKinnon's paper), and the overvaluation of the US dollar at the end of the dollar bubble in 1981-1984 is another example. Furthermore, Yip notes that the phenomena of herding behavior and exchange rate overshooting could result in big cycles and high volatility of exchange rate under a floating regime. In fact, we have seen, on and off, quite a number of big and long cycles of major floating currencies such as the US dollar, euro, yen and sterling over the last few decades. Thus, policymakers should bear in mind that exchange rate experiences and theoretical developments since the 1970s suggest that flexible exchange rate is not as perfect as that presumed by proponents of the regime in the late 1960s (e.g., Johnson, 1969; Friedman, 1969).

\subsection{The real choice of exchange rate system for most economies}

In view of the relatively small benefits as well as the huge economic adjustment costs and vulnerability to speculative attacks under the fixed exchange rate system, Williamson believes that the real choice for most countries lies between freely floating rates and some kind of intermediate regime such as floating rates with a reference rate system, managed floating or $\mathrm{BBC}$ regime. Yip also notes that the phenomena of herding behavior and exchange rate overshooting could result in undesirable outcomes in China if she adopts a floating regime in the 2000s. Instead, he recommends more detailed studies of the interesting and desirable features in: (i) the monitoring band system in Singapore ${ }^{1}$ and (ii) a floating regime with occasional major interventions. Chow also reports that the exchange rate system in Singapore has enabled her to cope with the Asian financial crisis, even though her neighbors were seriously hurt by the crisis.

\footnotetext{
${ }^{1}$ Note that Yip also warns that a mere adoption of Singapore's system without appropriate adaptations could be disastrous. Thus, appropriate modifications of the monitoring system to suit the major economic characteristics of the adopting economy are important to the success of reform.
} 
Despite reservations on the feasibility of the reference rate system in Williamson's current paper, the editor agrees with him that it is possible to design an intermediate regime in a form that avoids the hard bands that provoke crises, e.g., BBC regimes without hard edges to the bands. One promising and proven to be successful example is the monitoring band system that was first proposed by Williamson (2000), further refined and improved by Yip (2003, 2005a), and actually implemented in Singapore. Policymakers are highly recommended to have a careful reading of the articles and book for more details, including its advantages in: (a) maintaining credibility and yet allowing for sufficient exchange rate flexibility with respect to normal internal or external shocks as well as extremely adverse shocks such as the Asian financial crisis in 1997; (b) discouraging herding behavior and hence, big cycles in the exchange rate; and (c) allowing continuous adjustment of exchange rate to avoid accumulation of exchange rate misalignments that could provoke crises. Finally, the editor believes it is better to avoid grouping various types of non-polar regimes (i.e., neither fixed rate nor free floating regimes) into a big group of intermediate regimes. As highlighted by Yip in this volume, a viable exchange rate system involves right and mutually consistent decisions in all the relevant dimensions or characteristics of the systems (e.g., degree of flexibility, width of band, soft or hard bands, etc.) as well as other characteristics of the adopting economy. In particular, inconsistent decisions on the different dimensions could result in a complete failure. Thus, grouping the multidimensional exchange rate systems into a simple intermediate regime could be misleading and dangerous.

\section{Capital Control and Speculative Attacks}

Lim's paper in this volume notes that China and the new ASEAN 4 were not much affected by the Asian financial crisis, mainly because there was capital control in these economies. Meanwhile, with a reasonably high degree of capital mobility and inherent weakness in the economic system, Indonesia, Thailand, Philippines and Malaysia suffered a lot from the speculative attacks in 1997-1998. On the other hand, after the adoption of capital control in August 1998, Malaysia was no longer subject to speculative attacks and was able to recover from the recession without resorting to the IMF loans. Lim also notes that Japan, South Korea and Taiwan all had important capital control at their early stage of (rapid) economic growth. Thus, at the early stage of economic growth, when speculative attacks on their currencies can be frequent and disastrous, capital control can help insulate the developing economies from speculative attacks and hence contribute to exchange rate stability. While admitting that capital control is never the most desirable option or target to pursue, Lim also highlights that capital account liberalization could and should usher in the liberalization of the domestic economy, particularly the strengthening of the financial infrastructure and the liberalization of both foreign and domestic trade. [Postscript: With excessive capital inflows and monetary growth, rampant asset inflation and then high CPI inflation for years, there was eventually an outbreak of crisis in Vietnam in June 2008. The Editor is of the view that there are important lessons to be learned from (a) the causes and experiences of Vietnam's crisis; and (b) the differences and similarities between China's and Vietnam's latest experiences. He also believes that the effectiveness of capital control in Vietnam will be the key on 
whether the country can go through the crisis with less unbearable economic and political damages.]

Lim's view is in fact shared by many prominent economists, including McKinnon who has in the past expressed a similar view. In the detailed discussion of China's exchange rate system reform in this volume, Yip also uses the doctrine of Impossible Trinity to highlight China's needs to maintain a sufficient degree of capital control in the medium future (i.e., at least in the next 8-10 years) so that she can control her money supply (to finetune the aggregate demand) and monitor the appreciation rate of renminbi (to avoid coordination failure in the economic system as well as unnecessary disruptions to exports, output and employment). Drawing from the experience of crisis-hit Asian economies in 1997, he also notes that a list of prerequisites should be satisfied before China can consider complete liberalization of her capital account. For example, China should maintain a sufficient degree of capital control at least until (i) the problem of non-performing bank loans and extensive moral hazard activities are cleared, and (ii) the real exchange rate has gradually adjusted to levels reasonably close to its equilibrium level. That is, removing capital control should be the last step of the reform.

For Japan in the 1970s to mid-1980s, Takagi also notes the contribution of changes in capital control regulations in smoothing the abrupt changes in the value of the yen. Dua and Sinha also report that, unlike the crisis-hit economies who adopted complete or a significant degree of capital control before 1997, India's capital account reforms with reasonable degree of capital control after the 1991-1992 crisis have contributed to her relative insulation from the Asian financial crisis in 1997.

Thus, a few conclusions can be drawn from the discussion on capital control. For small developed city-economies such as Hong Kong and Singapore whose benefit of becoming an international financial center is relatively large, it is advisable to have free capital mobility which is a prerequisite of an international financial center. Similarly, for developed economies whose financial system is reasonably sound (i.e., no significant inherent weakness) and real exchange rate is not significantly misaligned, the contributions of free capital mobility (i.e., more efficient allocation of capital) will be greater than that of capital control. However, for large and medium (developing) economies whose financial system and exchange rate level are vulnerable to speculative attacks, one has to be extremely careful in liberalizing her capital account. In fact, as noted by McKinnon and Takagi, with a significantly misaligned dollar value and rapidly growing international capital mobility by 1971, even the US was unable to stand against speculative attacks on the dollar.

\section{Undervaluation of Yen: A Threat to Global Financial Stability?}

Let us now come to McKinnon's discussion on the current undervaluation of the yen and the low interest rate in Japan, which is related to the very hot topic of "yen carry trade"2 and could be a potential cause of global financial turmoil in the future.

\footnotetext{
${ }^{2}$ An example of yen carry trade noted by McKinnon is as follows: a speculator, who need not be a Japanese national, borrows short in Tokyo in yen at less than $1 \%$ in order to invest long-term in 10-year Australian government bonds bearing $6.27 \%$.
} 


\subsection{Currency mismatch, low interest rate, carry trade and run of yen}

Both Williamson and McKinnon in this volume indicate that the current yen is substantially undervalued, reflecting that this could be a common view among policymakers and economics academia in the US. Williamson believes the undervaluation of yen could be as much as 30\%; McKinnon's comparison of real wages in Japan, Europe and the US also suggests that the real undervaluation of yen is substantial. McKinnon goes further in explaining how Japan is trapped by the undervalued yen and the currency mismatch between the huge US dollar claims and yen liabilities of Japanese mainline financial institutions such as insurance companies and banks:

“... Although Japan is the world's largest creditor country, it does not lend much in yen because of the currency asymmetry associated with the dollar standard. Instead, the country's large current account (saving) surpluses are partially financed by outward foreign direct investment, but mainly by building up foreign currency claims (mainly dollars) on foreigners (Table 2). This leads to a currency mismatch within Japan's economy.

In the private sector in particular, financial institutions such as insurance companies or banks acquire higher-yield dollar assets even though their liabilities are mainly in yen - as are their annuity obligations to policyholders or to depositors. Although these financial institutions have come to depend on the higher yield on dollar over yen assets, they fear any fluctuation in the yen/dollar exchange rate that would change the yen value of their dollar assets relative their yen liabilities. Even a random upward blip (appreciation) in the yen could wipe out their net worth. So they will hold dollar assets only if they are given a substantial risk premium for doing so."

“... Because of the currency mismatch, this negative risk premium will be higher (more negative) the greater the fluctuations in the yen/dollar rate and the larger are Japan's private holdings of dollar assets. Figure 13 shows that, in the absence of secular appreciation of the yen since 1995, the yen/dollar rate has still fluctuated very substantially.

Japan's current account (saving) surpluses only became significant in the early 1980s. But more than 20 years later, the cumulative total of liquid dollar claims held by the economy is now much greater relative to GNP than it was back in the 1980 s — and it is continually growing (Table 2 )..."

Thus, Japanese banks, insurance companies, trust funds and even some individuals are willing to hold the existing huge amount of US dollar assets only if they are given a substantial risk premium (i.e., substantial differential between the US and Japanese interest rates). However, with a close to zero interest rate and hence a limit in the risk premium, the system becomes vulnerable to any news that could trigger an expectation of yen appreciation or run for yen, and the Bank of Japan (BoJ) is forced to intervene in the foreign exchange market 
to stop the yen from appreciating:

"... once there is a run, during which the BoJ buys dollar assets from the private sector on a large scale, Japanese insurance companies, banks and so forth, eventually become happy holding their remaining smaller stocks of dollar assets if and when they finally decide that the BoJ can hang on without letting the yen appreciate (further). After a run, these institutions may even be willing to rebuild their depleted stocks of higher-yield dollar assets for many months or years — thus providing finance for the ongoing current account surplus without the BoJ's intervening at all."

McKinnon also notes that: (i) the above mechanism also applies to yen carry trade; (ii) the size of the currency mismatched assets held by mainline Japanese financial institutions is much greater than that of carry trade; and (iii) carry traders have raised the exchange rate risk, and hence the required risk premium, of mainline Japanese financial institutions, which could in turn increase the likelihood and frequency of run for yen:

"... the carry trade does contribute to the potential volatility of the yen/dollar exchange rate. With any hint of, or rumor that, the yen might appreciate, carrytrade speculators with their short-term yen liabilities may well react first. They rush to cover their short positions in yen by not renewing loans or simply buying offsetting yen assets. This quickly adds to the upward pressure on the yen so as to trigger a run that induces mainline financial institutions to start selling off their dollar assets as well, which the BoJ buys as per the positive spikes of official reserve accumulation in Figure 15. By making the yen/dollar rate more volatile, carry traders heighten the exchange risk to mainline financial institutions. Thus, indirectly, do carry-trade speculators widen the interest differential between dollar and yen assets necessary to maintain (an uneasy) portfolio equilibrium where mainline Japanese financial firms hold some of both."

\subsection{Japan is caught}

According to McKinnon, because of the worry of an abrupt appreciation of the yen,

(a) Japanese exporters were extremely cautious in revising wages up with productivity growth (i.e., with wage increment based on the current (undervalued) yen, a sudden reversal of the yen can easily change their business from profit-making to loss-making). As a result, Japanese wage increments have lagged behind those in Europe and the US, which has in turn increased the real undervaluation of the yen. The sluggish wage has also dampened Japan's private consumption and hence recovery from the lost decade, even though Japanese exports have achieved moderate growth in recent years. ${ }^{3}$

\footnotetext{
${ }^{3}$ Note that this is likely to be an argument for a delay in wage increment instead of a permanent stagnation of wages. With greater and greater relative real wage gap between Japan and the industrialized economies of the US and Europe, relative real wage in Japan will sooner or later be revised up, albeit with a delay.
} 
(b) Japanese lending and deposit rates were low, with the deposit rate being close to the floor of zero. ${ }^{4}$ This in turn implies a low lending-deposit interest margin which has contributed to the slow clearing of non-performing bank loans caused by the bursting of the asset bubble. With banks' lending ability still constrained by the non-performing loans, it is hard for Japan to emerge from the lost decade in a more promising pace. ${ }^{5}$

\subsection{A potential threat to global financial stability?}

So far is what has been discussed in McKinnon. What I would like to go further from here on is the following question: if a run for yen is big enough, is it possible that the BoJ might eventually choose not to intervene? What would happen in such a case? To answer these questions, first note that the BoJ foreign exchange market intervention (to stop the yen from appreciating) involves purchases of the US dollar and sales of yen, and the BoJ has the right to print as much yen as it likes. Thus, if it ever wishes to, the BoJ can deal with any size of run for yen. Nevertheless, it is still possible that the BoJ may no longer wish to stop the yen from appreciating when the cost of intervention (say, in terms of excessive money supply and inflationary pressure) is higher than the cost of not intervening. To see this, let us first discuss the mechanisms during the normal period and run for yen period with the help of Tables 1(a) and 1(b).

Table 1(a). Normal Period

\begin{tabular}{|c|c|}
\hline Activities and Counteracting Force & Effect on the Foreign Exchange Market \\
\hline $\begin{array}{l}\text { Japanese FIs and yen carry traders } \\
\text { use their yen borrowings to acquire } \\
\text { US dollar claims }\end{array}$ & demand US dollar \\
\hline Japan's current account surplus & supply US dollar \\
\hline
\end{tabular}

Table 1(b). Run for Yen Period

\begin{tabular}{lcc}
\hline Activities and Counteracting Force & Effect on the Foreign Exchange Market \\
\hline $\begin{array}{l}\text { Japanese FIs and yen carry traders } \\
\text { run for yen to unwind their currency } \\
\text { mismatch exposures }\end{array}$ & supply US dollar & demand yen \\
BoJ's FOREX market intervention & demand US dollar & supply yen \\
\hline
\end{tabular}

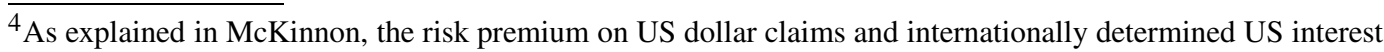
rate would imply low interest rates in Japan. In addition, the sluggish economy has also resulted in a low lending rate in Japan.

${ }^{5}$ Note, unlike the case of wage increment, this argument could be permanent (i.e., with the required risk premium, Japanese interest rate could stay low forever). In addition, Japan could stay in a vicious cycle of low aggregate demand and weak bank lending activities.
} 
During the normal period, most of the effect of Japan's substantial current account surplus will be offset by Japanese mainline financial institutions' (FIs) and yen carry traders' borrowing and investment activities (i.e., use their yen borrowings to acquire US dollar, or other foreign currency, claims). Thus, during the normal period, the BoJ was able to control Japan's money supply with only a small open market operation.

During the run for yen period, the BoJ will supply huge amounts of yen (and demand US dollar) in the foreign exchange market to meet the Japanese financial institutions' and yen carry traders' demand for yen. If the BoJ's intervention manages to, as it has been able to, clam the market so that the run is only temporary and Japanese financial institutions and yen carry traders are thereafter happy to hold the US dollar claims, then things will very soon return to normal. In the whole process, only a small portion of the US dollars was unwound for a short period, with which the Japanese economy and the global financial market have no problem to absorb. However, suppose there is a change in market fundamentals that eventually convince the Japanese bank and non-bank sectors to unwind their dollar claims on a more long-term basis, the BoJ intervention will imply a huge supply of yen and hence a multiple creation of Japan's domestic money supply for a prolonged period. Unless the Japanese government is able and willing to sterilize this with sufficient issuance of government bond, this will be extremely inflationary. ${ }^{6}$ According to McKinnon, Japan's cumulative total of banks' and non-banks' net liquid dollar claims has already reached a huge sum. I am not sure whether this would exceed the Japanese government's capacity or willing limit of sterilization. If yes, then the implied inflationary pressure would eventually force the BoJ to give up the foreign exchange market intervention. By then, the substantially undervalued yen will start to shoot up, which would induce more inflows, and run, for yen. Obviously, the BoJ will try to smooth the yen appreciation even if it has decided to give up the intervention eventually, but the shock to the global financial and property market associated with the currency-match unwinding and the induced speculative inflows for yen could be sufficient to cause a crisis and hence, a global recession. The shock and disturbance to the Japanese and global economies arising from these relatively fast major realignments of the yen's exchange value against other currencies will also be huge.

How likely is this horrible scenario? My tentative view is: not that easy, but not impossible. Given the potential damage of not intervening amid a run for yen, it is obvious that the BoJ will intervene and the Japanese government will sterilize the implied money creation whenever possible. So, the key here is the relative size of the potential run (i.e., sum of Japanese private sectors' net dollar claims, yen carry traders' borrowings and speculative inflows) and Japanese government's willing limit of sterilization. However, even if the former is still within the limit of the latter, continued undervaluation of yen and continued accumulation of liquid dollar claims by the Japanese private sector could one day reverse the situation. Another question is what "market fundamentals" can convince Japan's private sector to unwind its liquid dollar claims on a more long-term basis and in a large enough

\footnotetext{
${ }^{6}$ Because of the floor of zero interest rate, Japan's interest rate may not be able to fall further to discourage the inflows.
} 
scale. Will a recovery of the Japanese economy, which could cause a stock market boom or strong recovery of property price, be able to do so? Will the growing risk of a plunge in global financial asset price, which would induce the unwinding (and hence increase the likelihood and depth of the crisis), be able to do so? As it is too ambitious an aim for this Introduction to provide an answer to the whole issue, I will leave these very important questions for further rigorous study by national or international policy research institutes or academia.

Another related issue, and perhaps a solution of the above problem, is on the latest developments. With the recent substantial depreciation of the US dollar, the undervaluation of Japan's nominal effective exchange rate (NEER) could have been reduced. However, this would also mean an emergence or deepening of Europe's NEER overvaluation. That is, Europe and other floating currencies are not just losing their relative price competitiveness relative to the US, but are also losing their competitiveness relative to Japan, whose currency is more or less following the fall of the US dollar. Worse still, with the sustained years of sluggish wage in Japan and the relatively high wage growth in Europe highlighted by McKinnon, Europe's NEER could have been substantially overvalued. If so, after further rallies of the euro, will there be substantial depreciation of the euro in the longer future? That is, we might be seeing big cycles in major currencies such as the euro, sterling, Australian dollar and so on. This comes back to our Section 2's reminder against the presumed perfection of the floating exchange rate regime. [Note, with the depreciation of the US dollar in the first stage and the depreciation of other floating currencies in the second stage, ${ }^{7}$ perhaps the above problem of yen undervaluation will be cleared. Of course, we have to hope that this happens before an uncontrollable run for yen.] [Postscript: Since the publication of this article in the Singapore Economic Review in December 2007, there were further depreciations of the US dollar vis-à-vis the euro and a temporary run for yen in February-April 2008 due to the subprime crisis in the US. However, from May 2008 onwards, changes in the expected market fundamentals (i.e., the market expected no further cut in interest rate and anticipated that the forthcoming election would mean the end of the weak-dollar Bush regime) had resulted in a rebound of the US dollar, and suggested that the US dollar might have already gone through its local trough and there could be major correction of the euro from the current unsustainably high level in the longer future. If so, it is possible that the world could clear the yen undervaluation and avoid the above run-for-yen crisis with a major correction of the US dollar at the first stage (already happened), and then another major correction of the euro and other floating currencies in the second stage (could happen in the longer future). For example, despite temporary runs for yen, the yen-US dollar rate on 16 June 2008 was 108.08, not much different from the 108.94 on 16 June 2005. On the other hand, the US dollar had depreciated by more than $20 \%$ against the euro during the same period (i.e., from 1.2115 to 1.5459$)$. Of course, even if we could avoid the run-for-yen crisis in this way, there would still be big exchange cycles in the US dollar and the euro along the whole process. These would in turn have substantial impacts on the outputs of the related economies.]

\footnotetext{
${ }^{7}$ Note that both the US dollar and the euro will probably overdepreciate in the first and second stage. That is, there is likely to be overshooting and cycles of exchange rates in the whole adjustment process.
} 
Which economy can better deal with the potentially big cycle of exchange rate discussed above? I believe the answer is Singapore, which would usually maintain her NEER appreciation target unless there are changes in real factors or inflation. By targeting the Singapore dollar against a basket of currencies, the fluctuations of the Singapore dollar will be much smaller than that of the euro: when the euro rises (falls) against the US dollar, the Singapore dollar will rise (fall) against the US dollar by a smaller amount and fall (rise) moderately against the euro. That is, despite large nominal swings in individual floating currencies, Singapore can avoid changes in her competitiveness through an appropriate choice in her NEER target. For example, in the absence of changes in real factor and foreign-domestic inflation differential, maintaining a fixed trade-weighted NEER would mean no change is her relative price competitiveness during the whole exchange rate cycle. That is also why I have kept recommending the Chinese government to start convincing and send strong signals to the market that she is constantly "observing" the exchange value of her currency against a basket of currencies instead of against the US dollar. That is, given the various types of imperfections in China's financial system, China should leave the difficult job of dealing with the cycles in the US dollar (euro) to Europe (the US), but she would do her duty by following the nominal swings in a smaller scale through a relative stable NEER which would be adjusted with changes in real factors or relative inflation. Such a shift of focus to the NEER from the rate against the US dollar will also mitigate the US pressure for further renminbi appreciation.

\section{Remarks: Other Major Lessons}

Finally, I would like to list a few other important lessons as follows. Interested readers could refer to the related articles for more details.

\subsection{Control of asset inflation}

Yip notes that one underlying reason for the Asian financial crisis in 1997 was the prolonged and rampant asset inflation era before 1997. It also highlights that the major risk to the Chinese economy and her exchange rate system reform is in fact the stock market bubble and rampant property inflation formed in recent years. To keep asset inflation under control,

(a) it is always better to curb any potential rampant asset inflation (or asset bubble) during the early stages; and

(b) if an expectation of rampant asset inflation has been formed, much greater curbing measures are needed before the asset inflation can be properly controlled.

Policymakers should also be careful about rebounds in asset price from a trough. If the rebound has resulted in an established upward inertia and an expectation of further rises in the asset price, it could cause changes in economic behaviors, a few macroeconomic vicious cycles and herding behaviors, which will fuel the rise in asset price and bring the asset market 
into an automatic path towards the bubble. Past experiences in the US and Hong Kong as well as the recent experience in China suggest that such likelihood is much greater than most people believe. Finally, experiences in the East Asian economies before 1997 and China since 2006 suggest that the asset inflation will sooner or later spillover to the CPI inflation. It is sad that a substantial number of insufficiently or improperly trained economists in China has caused delay in the curbing of China's CPI inflation through their ignorant comments and recommendations.

\subsection{Exit strategy from a fixed exchange rate system}

In Section 2, we explained that a fixed exchange rate system is probably not the best choice for most economies. Nevertheless, an exit from a fixed rate system could involve a huge exit cost, especially if the currency is substantially undervalued or overvalued. Thus, careful exit strategy is necessary to bring the exit costs to an affordable level. In the fifth paper of this volume, we see how China has used a gradual appreciation with narrow band (i.e., an upward-sloping variant of a fixed exchange rate system) to get out from the horizontal fixed rate system vis-à-vis the US dollar, before proceeding to the next stage of reform. Yip (2005b) has also provided a discussion on the exit costs of, and exit strategy from, the currency board system in Hong Kong.

\subsection{China's experience of banking reform}

In Yip's paper in this volume, we see that the non-performing loan ratio in China's banking industry was at a vulnerably high level before the banking reform in 2005-2006. However, after the injections by the Chinese government, then by the new foreign strategic partners, and then by the new shareholders through IPOs, the capital adequacy ratio in the Chinese banking industry has increased to a much more healthy level. Despite the Chinese banks' high nonperforming loan ratio at the early stage, foreign strategic partners are interested in investing because they regard the injection as a fee paid to buy the "right" of doing, or participating in, banking business in the fast-growing Chinese economy. With the participation of the foreign strategic partners, there is a better likelihood of proper internal control in the future. This, together with the expected profit from the IPO allotments, has induced a lot of individual and institutional investors to inject funds into the Chinese banks through IPO subscriptions. Hence, China's experience in banking reform has provided a theoretically viable strategy for improving banks' capital adequacy ratio in other developing economies. Nevertheless, as noted by Yip, China still has to prove that the foreign strategic partners will be able to establish proper internal control and business-oriented lending mentality within the Chinese banks. Here, the role of foreign strategic partners is important as the size of their interests in the Chinese bank is much higher than the monitoring cost. On the other hand, shareholders' interests are so diffused such that the size of their interests is small relative to the monitoring cost. That is, one cannot rely on the shareholders to monitor the banks' behavior towards the desired direction. 


\subsection{US bashing could be misleading}

McKinnon is very much against the US bashing for yen appreciation, and believes the yen appreciation has caused the syndrome of the ever-higher yen:

"The expectation of an ever-higher yen led first to reduced nominal interest rates on yen assets, and contributed to the great bubbles in Japanese stock and land prices in the late 1980s. When the bubbles burst in 1990-1991, the deflationary pressure was reinforced by the further sharp appreciation of the already overvalued yen through to April 1995. The combination of an overvalued yen and the aftermath of the collapsed asset bubbles forced Japan's economy into a deflationary slump from which it has yet to fully recover."

He also recommends China to resist pressure for renminbi appreciation. Cheung et al. also note that the mere act of quickly revaluing renminbi — or of moving to a relatively free float - might in itself change the equilibrium exchange rate if it triggers corporate defaults or causes changes in the balance sheets of unhedged firms. The end of capital controls, either by fiat or by slow erosion, might also alter the equilibrium exchange rate. They believe that the US trade deficit is first and foremost a "made-in-America" problem, and it would be an enormous mistake to think that a stronger renminbi is a panacea for what ails the US. Other economists in the US also express concern that a rapidly appreciating renminbi would harm the US (say, in terms of consumer loss and inflation).

In the fifth paper of this volume, we can also see that China did not follow Japan's mistake by accepting secular appreciation. In fact, in my other recommendations to the Chinese government, I have indicated that if China bows to the US pressure for sharp appreciation, it will cause a lot of problems (e.g., enormous capital inflows though the illegal channels and abuse of legal channels, which will fuel the appreciation and/or cause rampant asset inflation through the greater money supply; the sharp appreciation will also cause a surge in China's unemployment rate to a socially painful level). By then, the Chinese leaders will be blamed by the Chinese people, and the US would have no incentive to correct the mistake. On the other hand, if China resists the US pressure, Chinese people will stand on the side of their leaders even if there is a trade sanction. As the US will also suffer from the trade sanction, there are incentives for the US to correct the mistake in the future. In a subsequent policy comment, I have also used the standard game theory result to highlight that the US threat of trade sanction is in fact a non-credible threat for a large economy such as China (i.e., it is not to the advantage of the US to honor the threat). By now, it is clear that China will not bow to the US pressure for sharp appreciation and capital account liberalization, although she does not mind making other non-detrimental concessions such as purchasing more US planes for the expansion of her airline fleets.

\subsection{Variable wage component}

Finally, Yip notes that the adoption of Singapore's variable wage component in the wage system will enable the adopting economy to cut the wage when deemed necessary. In view 
of the empirical evidence of substantial wage and price sluggishness, this will increase the flexibility of wages in the adopting economy. For example, in case of an overvaluation of domestic currency and an externally triggered recession such as that in Singapore in 1985-1986, the adopting economy can facilitate the recovery by cutting the variable wage component. In case of speculative attacks such as those in the Asian economies in 1997, a cut in the variable wage component will change the equilibrium exchange rate and help to fend off speculative attacks: a cut in wage amid a moderate depreciation will cause a rebound in exchange rate and hurt the speculators; in fact, speculators will have less tendency to attack the currency if they know the adopting economy can announce a nation-wide cut in wage when deemed necessary.

\section{References}

Friedman, M (1969). Round table on exchange rate policy. American Economic Review, 59(2), 364366.

Johnson, HG (1969). The case for flexible exchange rates. Federal Reserve Bank of St. Louis Review, $51(6), 12-24$.

Williamson, $\mathbf{J}$ (2000). Crawling bands or monitoring bands: How to manage exchange rates in a world of capital mobility. In International Economics and International Economic Policy: A Reader, P King (ed.). McGraw-Hill.

Yip, PSL (2002). A note on Singapore's exchange rate policy: Empirical foundations, past performance and outlook. Singapore Economic Review, 47(1), 173-182.

- (2003). A restatement of Singapore's monetary and exchange rate policies. Singapore Economic Review, 48(2), 201-212.

- (2005a). The Exchange Rate Systems in Hong Kong and Singapore: Currency Board vs Monitoring Band. Singapore: Prentice Hall.

- (2005b). On the maintenance costs and exit costs of the peg in Hong Kong. Review of Pacific Basin Financial Markets and Policies, 8(3), 377-403.

Yip, PSL and RF Wang (2001). On the neutrality of exchange rate policy in Singapore. ASEAN Economic Bulletin, 18(2), 251-262.

- (2002). Is price in Hong Kong that flexible? Evidence from the export sector. Asian Economic Journal, 16(2), 193-208. 